\title{
FATWA CONTRIBUTION TO THE DEVELOPMENT OF ISLAMIC LAW (STUDY OF THE FATWA INSTITUTE OF SAUDI ARABIA)
}

\author{
IBNU IRAWAN ${ }^{1}$, JAYUSMAN $^{2}, \&$ AGUS HERMANTO ${ }^{3}$ \\ Pascasarjana (PPs) UIN Raden Intan Lampung \\ E-mail: whanibn@gmail.com ${ }^{1}$, jayusman_falaq@yahoo.co.id, ${ }^{2}$ gusher.sulthana@gmail.com ${ }^{3}$ \\ DOI: $h$ ttp://dx.doi.org/10.24952/fitrah.v5i1.1979

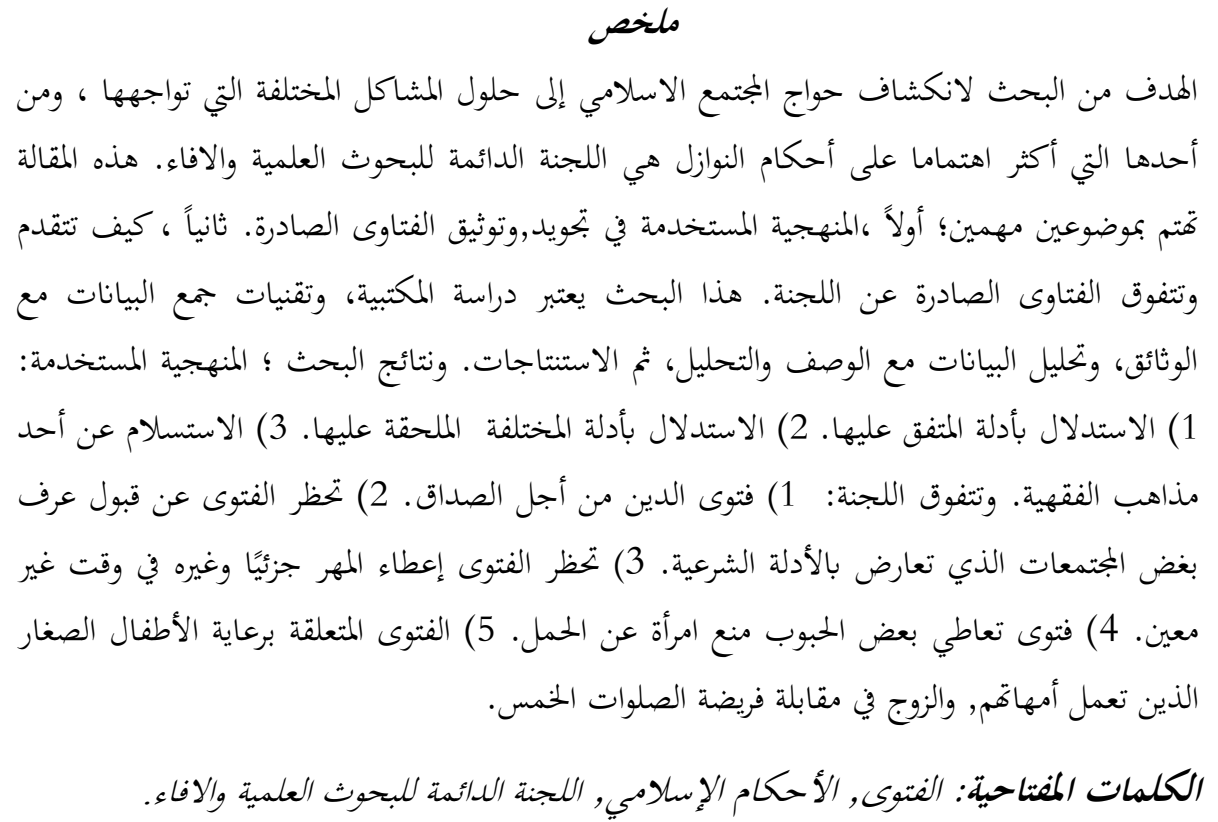

\begin{abstract}
Abstrak
Penelitian ini bertujuan untuk mengungkap ramainya kebutuhan masyarakat atas solusi dari berbagai persoalan yang di hadapinya, salah satu lembaga fatwa yang konsen merespon isu-isu nawazil adalah lembaga fatwa Arab Saudi ; Al-lajnah al-Daimah Li al-Buhus alIlmiyah Wa al-Ifta, dalam artikel ini penulis mengangkat tema seputar; Pertama, metodelogi yang digunakan dalam mengistinbantkan hukum dari pertanyaan yang diajukan. Kedua, bagaimana progresifitas dari fatwa-fatwa yang dikeluarkan oleh lembaga tersebut. Penelitian ini merupakan jenis penelitian pustaka, teknik pengumpulan data dengan dokumentasi, analisa data dengan deskriptif analisis, kemudian kesimpulan. Hasil analisis menunjukkan bahwa; metodologi yang digunakan; 1) Senantiasa merujuk dan berasakan dalil-dalil yang bersifat muttafaq. 2) Menjadikan dalil-dalil yang bersifat mukhtalaf sebagai bahan
\end{abstract}


FITRAH Jurnal Kajian Ilmu-ilmu Keislaman

Vol. 05 No. 2 Desember 2019

pertimbangan dalam memutuskan suatu persolan. 3) Tidak cenderung terhadap aliran dan mazhab tertentu. Progresifitas dari fatwa-fatwa yang dikeluarkan antara lain; 1) Fatwa pembolehan berhutang untuk keperluan pernikahan. 2) Fatwa larangan menerima tradisi yang tengah berlangsung pada masyarakat tertentu dan bertentangan dengan agama. 3) Fatwa larangan memberikan mahar sebagian saja dan sebagian lainnya di lain waktu tanpa kepastian waktu. 4) Fatwa penggunaan obat-obatan agar rahimya tidak dapat hamil lagi. 5) Fatwa terkait pengasuhan balita yang ibunya sedang bekerja.

Kata Kunci: Fatwa, Hukum Islam, Al-Lajnah al-Daimah Li al-Buhus alIlmiyah Wa al-Ifta.

\section{INTRODUCTION}

The continuity of Islamic law will be greatly helping by the presence of fatwas from individuals and institutions. The fatwa is not something foreign to the understanding of Indonesian people; with the permission of Allah, there is an official state institution that accommodates fatwas in Islamic law, although an institution or individual does not limit fatwas. If someone has arrived and is sufficiently knowledgeable, then his fatwa can be accepted and carried out, ${ }^{1}$ and even awaiting his presence.

This culture has been going on for centuries since the time of Islam was present in the Arabian peninsula until today in various regions. The fatwa is a gift from God Almighty, for Muslims, with which Muslims are greatly helped in studying, digging up information, seeking knowledge on a starting problem, the duty of a mufti is to explain, teach, convey and answer information needs for every Muslim problem. ${ }^{2}$

Fatwas and their contributions become interesting to be studied more deeply. One of the productive fatwas in issuing fatwas is Al-Lajnah al-Daimah Li al-Buhus al-Ilmiyah Wa al-Ifta in responding to various questions raised by him. The answer is not only given to the questioner [المستفتي] regarding the questions that we're asking, but the institution tried to compile it and save the archives of

${ }^{1}$ Some things that should be fulfilled for a mufti include: 1) Mastering and understanding the basics of fiqh and their knowledge. 2) Having the ability that is capable (Arabic, al-Qur'an, interpretation) to determine an issue that has not been explicitly argued about it. 3) mastering all the knowledge that forms the basis and foundation of acting as a mufti. Muhammad al-Muqlub AlSyinqiti, Syarh Al-Waraqat Fi Usul Al-Fiqh (Beirut: Wazarat al-Auqaf Wa al-Tauzi', 2001).

${ }^{2}$ Abdurrazak Abdullah Salih bin Ghalib Al-Kindi, Al-Taisir Fi Al-Fatwa Asbabuhu Wa Dawabituhu (Beirut: Muassasah al-Risalah Nasyirun, 2008). 
the fatwas issued so that they can be used and used as a basis by various elements of the community.

The institution with its various advantages and disadvantages, the authors are interested in raising various things about the institution in the theme of the contribution of the fatwa in the development of Islamic law, among others; First, the methodology used in terminating the law of the questions asked. Second, how the progress of the fatwas issued by the institution. So with these two problems, the focus will be seen how the urgency of the fatwa itself in continuity, even the development of Islamic law.

\section{RESEARCH METHODS}

This study uses a qualitative method. This type of research is library research. The primary data source of this research is the main book of the fatwas of al-Lajnah al-Daimah Li al-Buhus al-Ilmiyyah Wa al-Ifta, which has been codifying in the form of book bundles. Secondary data from this research are classic books that have been discussing many themes around fatwas or in the discussion of ijtihad. The technique of collecting data through documentation is to collect various data related to themes about fatwas, fatwa institutions, or methodology in the fatwa. For data analysis with description and analysis, conclusions can be drawn, and future work or suggestions can be drawn.

\section{RESEARCH AND DISCUSSION}

\section{Fatwa Definition and Its Position in Islamic Law}

The etymological understanding of fatwa means something young, new, and explanatory. ${ }^{3}$ The fatwa is explaining the problem that was muftied by mufti for mustafti. ${ }^{4}$ Ibn Faris combines two syllables, namely: explain and fatwa, which means that the fatwa serves to explain the status of the new law. ${ }^{5}$

While various jurists provide information about the definition of fatwa in etymology, which means an activity explaining Syariah law that asking to a mufti, Yusuf al-Qardawi explained, ${ }^{6}$ the above understanding is similar to that

${ }^{3}$ Jamaluddin Ibnu Manzur Muhammad bin Mukrim bin Ali, Abu al-Fadl, Lisan Al-Arab (Beirut: Dar Shadir, 1414).

${ }^{4}$ al-Fairuz Abadi, Al-Qamus Al-Muhit (Cairo: al-Hai'ah al-Ilmiyah al-Misriyah, n.d.).

${ }^{5}$ Abu al-Husain Ahmad bin Faris Zakaria, Mu'jam Maqayis Al-Lughah (Beirut: Dar al-Fikr al-Arabi, n.d.).

${ }^{6}$ Yusuf Al-Qardawi, Al-Fatwa Baina Al-Indhibat Wa Al-Tassaub (Cairo: Dar al-Sahwah Li alNasyr Wa al-Tauzi, 1988). 
FITRAH Jurnal Kajian Ilmu-ilmu Keislaman

Vol. 05 No. 2 Desember 2019

described by John, L. Esposito, in the Oxford Muslim Encyclopedia World. ${ }^{7}$ alQarafi said that the fatwa is information from Allah, in a Syariah law 'and is binding or obligatory (ilzam).

Meanwhile, al-Banani gave a statement that was similar to before but was not binding, ${ }^{8}$ Abu Zahrah defines the same. ${ }^{9}$ The fatwa is to explain the law of a general problem, according to al-Jurjani. ${ }^{10}$ As for al-Bahuti, he explained the fatwa was to explain the issues surrounding syariah law to the questioner. ${ }^{11}$

From Various definition mentioned above and for what is being concern, fatwa is not same as ijtihad. Fatwa arises from the crossing of a mustafti who asks the problem experienced or wants to be known, whereas ijtihad ${ }^{12}$ is general in nature which is done through various istinbat propositions to explain the possibility law of an issue. ${ }^{13}$ The essence of various meanings mentioned by jurists around the fatwa, namely, first; fatwa is responsive, ${ }^{14}$ that consumers know that the students, he is a legal opinion that was only raised after being asked for information about the legal aspects of a Syariah problem 'by mustafti. Second, the legal force of fatwa does not always bind or must be followed by the contents of the law given to him, both fatwa issued by official institutions or individuals. ${ }^{15}$ So, it is being understandable that fatwa is a legal force to support or to reject the issues given by official institution or even from individuals.

This is based on a mufti in a place that can be different from the opinion of another mufti who is not in the same place, however, if the court considers this fatwa, then the fatwa has binding legal force, or the fatwa is qanunisasi become positive law in a certain region or region. While the elements involved in a fatwa, namely; First, the activity of explaining the Syariah law 'in response to the question asked is ifta' [استفتاء]] . Second, a person or group that asks is called (1990): 13.

${ }^{7}$ John L. Esposito, “The Oxford Encyclopedia of The Modern Islamic World," "Fatwa" II

${ }^{8}$ Tajuddin Abdul al-Wahab Ibnu Subki, Hasyiah Al-Allamah Al-Banani Ala Jam'i Al-Jawami' Bi Syarh Al-Muhalla (Beirut: Dar al-Halabi, 1997).

${ }_{9}^{9}$ Muhammad Abu Zahrah, Usul Al-Fiqh (Cairo: Dar al-Fikr al-Arabi, 1997).

${ }^{10}$ Ibrahim Al-Abyari, Al-Ta'rifat Li Al-Jurjani (Beirut: Dar al-Kutub al-Arabi, 1405).

11 Al-Bahuti, Syarh Muntaha Al-Iradiyat (Beirut: Dar al-Fikr al-Arabi, n.d.).

12 There are at least a number of important principles of Ijtihad: 1) Do not damage the foundation of faith. 2) Does not eliminate human dignity. 3) Priority of public interest. 4) Does not violate human morality. Mahjuddin, Masail Al-Fiqh (Jakarta: Penerbit Kalam Mulia, 2012).

${ }^{13} \mathrm{Ibnu}$ al-Hajib Abi Amr Jamaluddin Usman bin Umar bin Abi bakr, Syarh Al-Adhi 'Ala Mukhtashar Al-Muntaha (Beirut: Dar al-Kutub al-Alamiyah, 2000).

${ }^{14}$ Sa'di Abu Habib, Al-Qamus Al-Fighi (Damaskus: Dar al-Fikr al-Arabi, 1988).

${ }^{15}$ Ibrahim Al-Abyari, Al-Ta'rifat Li Al-Jurjani (Beirut: Dar al-Kutub al-Alamiyah, 1405). 
mustafti. Third, the person who answers the question is called mufti. Fourth, legal answers to the questions asked, and this is what is called a fatwa.

Fatwas have a very important existence in Islamic law. The contribution of fatwa in maintaining the continuity of Islamic law amid the state of Muslims, the role of fatwa as qada' is indeed important, as well as a method of interpretation and implementation of all Islamic laws that are still universal. While fatwas have a flexible ${ }^{16}$ and specific nature in a particular case, a certain place, and a certain time, such flexibility that supports Islamic law is considered [صالح لكل زمان ومكان]. ${ }^{17}$ Therefore, the fatwa is classified as having a very important position and existence in dynamizing Islamic law in every Muslim life through a response to various problems that arise during community life, which are certainly under the dimensions of the scope of time and conditions of a society. ${ }^{18}$

\section{Legal Sources in Fatwa}

The sources referred to in the fatwa will be explained as follows: First, the Qur'an. The jurists have widely mentioned understanding of the etymology and terminology of the Qur'an is the holy book, which is always the first backrest and is prioritized in every Syariah law or provision '.

Every mujtahid is not allowed to explore Islamic law before examining the arguments contained in the Koran first to be used as evidence, so if it is not found in the al-Qur'an, ${ }^{19}$ then it is permissible to look and turn to other postulates after al-Qur'an. In the understanding of al-Qur'an, the author is interested in what is conveyed by al-Syaukani regarding ta'rif al-Qur'an, as stated: the word of Allah Almighty, which was revealed to the Prophet Muhammad, which is writing in the Manuscripts, which is conveying to us naqli and mutawatir. ${ }^{20}$

This understanding contains an understanding of the exclusion of other books, hadith qudsi, hadith of the Prophet. Meanwhile, understanding related to

\footnotetext{
${ }^{16}$ Muraqi al-Falah Bi Imad al-Fattah Hasan bin Ammar bin Ali al-Syarniblali, Muraqi AlFalah, ed. Dar al-Kutub Al-Alamiyyah (Beirut, 2004).

${ }_{17}$ Anis Ubadah, Tarikh Al-Figh Al-Islami 'Ahd Al-Nubuwwah Wa Al-Sahabah Wa Al-Tabi'In (Cairo: Dar al-Fikr al-Arabi, 1980).

${ }^{18}$ Fathurrahman Djamil, Metode Ijtihad Majlis Tarjih Muhammadiyah (Jakarta: Logos Wacana Ilmu, 1995).

${ }_{19}$ Sulaiman bin Abdullah bin Hamud Aba Al-Khail, Masadir Al-Din Al-Islami Wa Abraz Mahasinuh Wa Mazayah (Riyad: Muassasah al-Risalah, 1431).

${ }^{20}$ Muhammad 'Ali ibn Muhammad Al-Syaukānī, Irsyād Al-Fukhūl Ilā Tahqīq Al-Haqq Min 'Ilm Al-Uşūl, (Beirut: Dār al-Kutub al-'Ilmiyyah, 1994).
} 
FITRAH Jurnal Kajian Ilmu-ilmu Keislaman

Vol. 05 No. 2 Desember 2019

the delivery of naqli and mutawatir ${ }^{21}$ also excludes the qiraat that is syaz. Thus, it can be understood correctly and validly that the Qur'an is a celestial book revealed to the Prophet Muhammad, but mutually, so that wholeness and originality are maintained, even awake from the qiraat that are syaz.

The content of al-Qur'an itself includes three important aspects in life: First, the i'tiqadiyah, namely the laws surrounding the belief of a believer in Allah swt, angels, His apostles, and the last day. Second, the of akhlakiyah, namely the laws that govern human behavior, both good and despicable behavior. Third, the amaliyah laws, namely the laws concerned between fellow humans, will also be fulfilled from the social aspects, cooperation, agreements between human beings.

The content of the al-Qur'an about amaliyah laws there are various details including, 1) al-ahkam al-'Ibadah, namely the laws around worship in a Muslim's daily life, including: prayer, zakat, hajj, fasting and jihad ; 2) al-ahkam al-ahwal alsyakhsiyah, which is a family law related to family problems that starts from the formation of the family, namely marriage, the relationship between the two spouses, and their relatives; 3) al-ahkam al-jinayah (criminal law), i.e., the laws that deal with criminal matters as a result of the sentence; 4) al-ahkam al-murafa'at (procedural law), namely the laws surrounding justice, testimony, and including oaths; 5) al-ahkam al-dusturiyah, the laws governing technical issues surrounding the formation of laws; 6) al-ahkam al-dauliyah, the laws governing interaction between international nations; 7) al-ahkam al-madaniyah (private law), namely the laws governing inter-individual, community and institutional business matters; 8) al-ahkam al-iqtisadiyah wa al-maliya, the laws around the economy and finance, which relate to the rights of the poor, economic resources, banking, and economic relations between individuals, communities, and countries. ${ }^{22}$

Secondly, the Sunah, in its meaning experiences a variety of perspectives, the usuli provide understanding related to the sunnahh that the sunnahh is every word, deed or taqrir which is sourced from the Messenger of Allah, which is the legal postulates outside the Qur'an. Meanwhile, the Jurists explained the meaning and understanding related to the Sunnah which means everything is originating from the Messenger of Allah, and all these things are not classified as fardu and mandatory. ${ }^{23}$

${ }^{21}$ Muhammad `Ali ibn Muhammad Al-Syaukānī....

${ }^{22}$ Abdul Wahab Khalaf, 'Ilmu Ushul Al-Figh (Cairo: Maktabah Da'wah Islamiyah, 1947).

${ }^{23}$ Muhammad Ajjaj Al-Khatib, Ushul Al-Hadis Ulumuhu Wa Mustalahahu (Beirut: Dar alFikr al-Arabi, 1989). 
Allah has revealed the Qur'anic revelation to humankind mediated by the Prophet Muhammad, to be a guide for life in the life of the world and as a guide to the afterlife. The majority of the teachings contained in the al-Qur'an are not necessarily able to be understood directly by humankind, but require parrots and explanations detailed by the sunah of the Prophet. All explanations conveyed by the Messenger of Allah, both in the form of statements or practical examples, are practically all of which can be referred to and understood as sunnah. Therefore, the sunah is a source of law that is absolutely inseparable from the Qur'an.

The correlation between al-Qur'an and sunnah are at least three important things, including the following: 1) the sunnah reinforces the laws contained in the al-Qur'an; 2) the sunah specifies the laws in the qur'an that are global in nature, the laws that are absolutely (مطلق) (مط limited by the sunnah and the general laws are specific to the sunnah; 3 the Sunah will determine ) laws that have not been filled or established by the Qur'an. ${ }^{25}$ On this basis Muslims agree that the sunnah of the Prophet Muhammad is a source of Islamic law. ${ }^{26}$

Third, Ijma' which is understood as the agreement of the mujtahids of the people of Muhammad, after he died, at one time, on a Syariah law. ${ }^{27}$ Ijma was still in the realm of contra agreement between mujtahid priests. The four Sunni schools of thought recognize ijma as a mustaqil or stand-alone and have a qat $i$ nature.

Nevertheless, the majority of jurists and mujtahids still doubt the possibility of ijma' after the period of companions, such as al-Shafi'i, Ahmad ibn Hanbal, Abu Muslim al-Esfahani, Ibn Taimiyah, and Ibn Hazm al-Zahiri. ${ }^{28}$ In other words, the majority considered ijma 'only to occur at the time of friends, even Muhammad al-Khuduri Bek, giving opinions about Ijma' which narrowed

${ }^{24}$ Mutlaq is absolute is a word or sentence that shows one or several objects freely without restrictions. Ali Muhammad Al-Amidi, Al-Ihkam Fi Ushuli Al-Ahkam (Riyad: Dar al-Shami'i Li alNasyri Wa al-Tauzi, 2003). As an example of the will sentence contained in QS al-Nisa verse 11, that the acquisition of the will contained in that verse is still absolute, without limitation, then the sunna as muqayid which limits the amount of obtaining a will is only one third and one third is considered to be many. Abu al-Muzafar Mansur bin Muhammad bin Abdul Jabbar Ibnu Ahmad alMaruzi Al-Sam'ani, Qawati Al-Adillah Fi Al-Usul (Beirut: Dar al-Kutub al-Alamiyah, 1998).

${ }^{25} \mathrm{~A}$ few of the Khawarij followers did not recognize al-sunnah as a source of Islamic law, which then gave birth to the concept of the [إنكار السنسة].Nasrun Rusli, Ijtihad Al-Syaukani (Jakarta: Logos Wacana Ilmu, 1999).

${ }^{26}$ Al-Syaukānī, Irsyād Al-Fukhūl Ilā Tahqīq Al-Haqq Min 'Ilm Al-Uşūl,.

${ }^{27}$ Abdul Wahab Khalaf, 'Ilmu Ushul Al-Figh.

${ }^{28}$ Zahrah, Usul Al-Figh. 
FITRAH Jurnal Kajian Ilmu-ilmu Keislaman

Vol. 05 No. 2 Desember 2019

the understanding of Ijma 'earlier. ${ }^{29}$ According to him, Ijma 'can only be taken, and the law only occurred during the period of Abu Bakr al-Siddiq and Umar bin al-Khattab, before the division among the people. While minorities such as Khawarij and Rafihah did not recognize the ijma's altogether rain..$^{30}$

Fourth, Fatwa Sahabah. A friend is known as someone who is always in the majlis of the Messenger of Allah, and always following him also narrated the hadith from the Prophet, as explained by Jalaluddin al-Suyuti. ${ }^{31}$ This understanding gives an important message as well as an indication of the conditions of the friends who can be accepted his opinion in determining the legal status of each problem, because how is it possible that the teachings of Islam explained by the Messenger of Allah, can be understood by someone who has only met him briefly or just a moment.

In the stipulation of the shariah law, the Messenger of Allah (saw) explained that it was based on an event that occurred in his day. Therefore, the tasyir process itself will be well understood and valid only by the companions who accompanied the Messenger of Allah constantly. Mentioned included in the group were Khulafaur Rashidin, Abdullah ibn Mas `ud, Anas ibn Malik, Zaid ibn Thabit, Abu Hurairah, and others. Based on this consideration, the Sunni judge Fatwa Companions are a legitimate source of Islamic law.

It is this background that underlies this thinking, because the companions intensively accompany the Messenger of Allah, and know his beginnings, then understand well how the process of tasyri 'took place and the methods adopted by the Prophet in determining a problem. Thus, the fatwa of Companions has an important existence in the establishment of Islamic law because: First, the Qur'an and Sunnah texts are understood to the next generation through the role of the Companions. Second, the best model of ijtihad is the istinbat method used by the Companions, ${ }^{32}$ as narrated by Maimun bin Mihran:

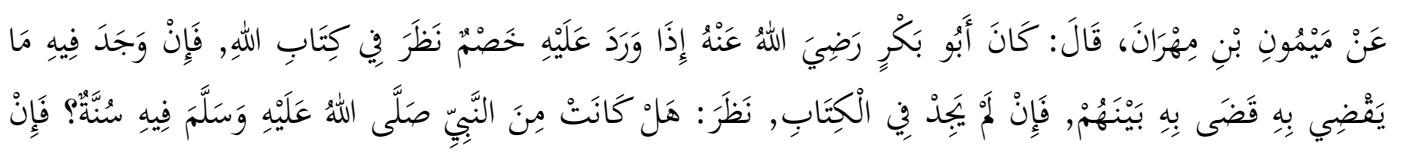

${ }^{29}$ Muhammad al-Khudurī Bek, Ushul Al-Fiqhi (Beirut: Dar al-Fikr al-Arabi, 1988).

${ }^{30}$ Muhammad 'Ali Al-Sāyis, Nasy'ah Al-Figh Al-Ijtihād Wa Ațwāuh (Jakarta: Raja Grafindo Persada, 1995).

${ }^{31}$ Abu Bakr Jalāluddīn Al-Suyūțī, Al-Rad 'Ala Man Akhlada Ila Al-Ardh Wa Jahl Anna AlIjtihad Fi Kulli 'Ashr Fardh (Cairo: Maktabah al-Saqafah al-Diniyyah, 2000).

${ }^{32}$ Al-Sāyis, Nasy'ah Al-Fiqh Al-Ijtihād Wa Ațzwāuh. 


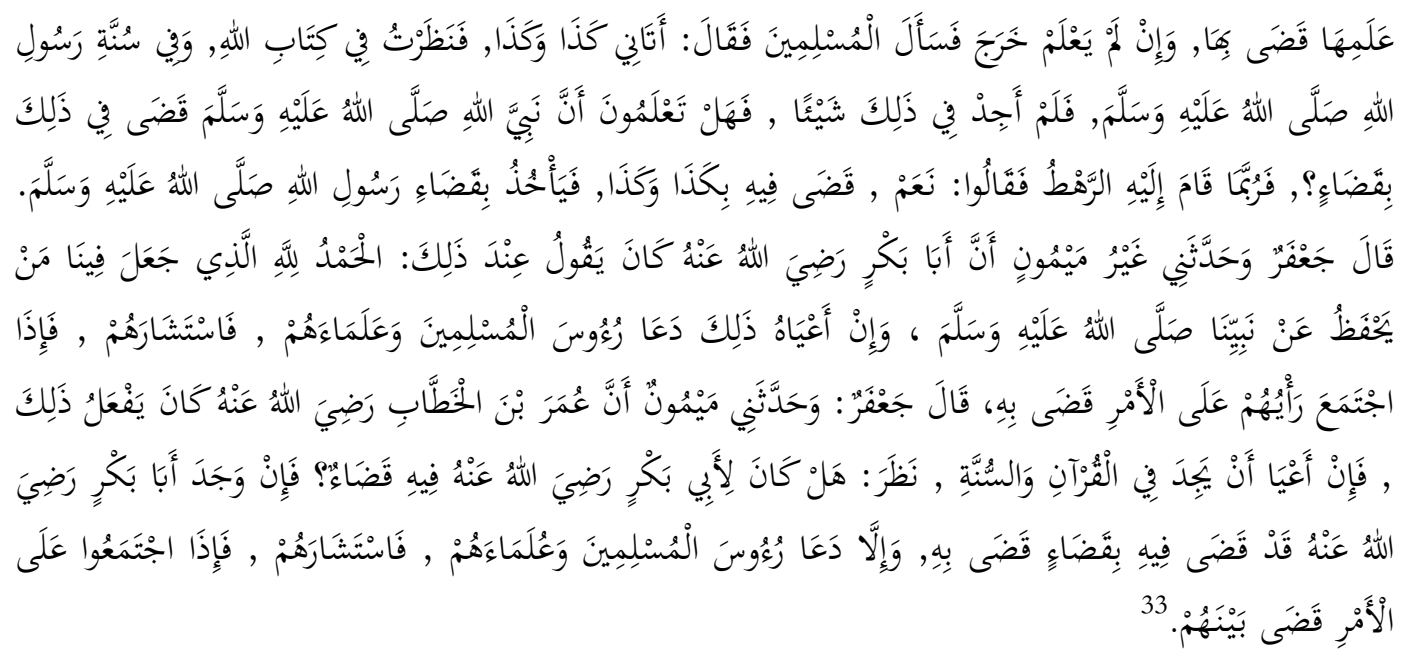

Abu Bakr, if there is a dispute that was submitted to him, he looked for it in the book of Allah. If the solution is in the book of God, then he uses the book of God. If it is not in the Book of Allah and he is found in the Sunnah, then he is punished by the Sunnah. If it is difficult to find, he goes out to ask others, and it has come to me of a case, have you ever seen the Messenger of Allah decide on the matter? Sometimes the group (which was asked) overall agreed to mention that there was a decision on the matter from the Messenger of Allah. If the group is difficult to find the sunnah, he gathered leaders and prominent people to deliberate. If their opinions are agreed upon, then he will decide the law with that opinion. Said Ja'far: at that time Abu Bakr said, all praise is only for Allah Almighty, who has made someone among his people who guard what is said by his Prophet. In another narration, Abu Bakr gathered all the leaders to deliberate, and the results were legalized.

Fifth, Fatwa of the Mujtahidin Imams. Rasulullah saw, sent his companions on an important mission, which served as the process of spreading Islamic teachings and fostering the Ummah to various parts of the region. After the death of the Messenger of Allah, on June 8, $632 \mathrm{AD},{ }^{34}$ with the condition of progress and expansion of Islamic territory, with the condition of the Companions of the Prophet, who is locating far from each other, they settled in areas that had the potential to spread Islamic understanding. So after the generation of Friends, the minutes and actualization activities were continued by the tabiin, tabiin-tabiin, and continued by the Imam of the mujtahidin.

${ }^{33}$ Abu Bakr al-Baihaki Ahmad bin al-Hasan bin Ali bin Musa al-Khusraujidi al-Khurasan, Al-Sunan Al-Kubra (Beirut: Dar al-Kutub al-Alamiyah, 1424).

${ }^{34}$ Muhammad Husain Haekal, Hayat Muhammad (Cairo: Dar al-Ma'rifah, 1995). 
FITRAH Jurnal Kajian Ilmu-ilmu Keislaman

Vol. 05 No. 2 Desember 2019

Difficult communication between the mujtahid imams because of the expansion of the Islamic jurisdiction plus the majority of mujtahid imams do not live in the same place or close together, the impact that occurs is the emergence of various opinions in legal matters that lead to the formation of fiqh schools. The variety of knowledge and understanding about the texts, especially the sunnah, is very influential in the outcome of mujtahid ijtihad (fatwa). So after many waves of abuse of the authority of ijtihad or called tala' $u b$ bi al-shari'a, ${ }^{35}$ some ulama falsely closed the door to ijtihad and suffers themselves with the opinions of the mujtahid ulemas who founded the school who are considered to have a foundation and anticipation for the development of Islamic law in the future. ${ }^{36}$ That background is considered to be a consideration that the fatwa of mujtahid imams falls into the category as a source of Islamic law.

The urgency of the mujtahid fatwa is: First, to help Muslims, in general, to understand the texts of the Qur'an and the Sunnah because, among the mujtahid imams, some obtain knowledge and understanding directly from the companions. Second, the methods used by the mujtahids are an important reference for the next generation of mujtahids in the process of determining the law. Because the mujtahid priests are not the same period of life, place of residence, the environment of life, and methods in ijtihad, so for those who will establish the law, open various legal options. Third, for the layman al-Nas (the general public who are not good at istidlal law directly from the text), then the fatwa mujtahid is a legal basis that can using as a basis or guidelines in performing certain acts or worship.

\section{The Istimbat Method in Fatwa}

A mufti is demanded to be able to immediately respond to every problem presented to him. Then at least have to go through legal istinbat from existing legal sources. Istinbat process will not get the right legal predictions, if not through the right methods. Therefore the usuli have compiled the rules regarding methods in resting or abstracting the law from available sources, there are at least three important things that help a mufti or mujtahid to restrain the law:

\footnotetext{
${ }_{35}$ Mustafa Al-Zarqa', Al-Figh Al-Islami Wa Madarisuhu (Beirut: Dar al-Qalam Li al-Tab'ah Wa al-Nasyr Wa al-Tauzi', 1996).

${ }^{36}$ Al-Suyūțī, Al-Rad 'Ala Man Akhlada Ila Al-Ardh Wa Jahl Anna Al-Ijtihad Fi Kulli 'Ashr Fardh.
} 
First, the Bayani Method. This method is also called the language analysis process by attempting to explain the Qur'an textually. The purpose of linguistic rules are rules that are constructed by linguists and then adopted by usuli which are used to understand the purpose and purpose of each lafaz contained in the Qur'an. ${ }^{37} \mathrm{Al}$-Qur'an and sunnah are sources of Islamic law that use Arabic, so to be able to take the maximum law from both of them, all knowledge about the ins and outs of Arabic is a necessity and a necessity. Al-Gazali states that Arabic rules are the pillars of fiqh proposals and are the basis for resting, because the content analyzed is the content of Arabic texts, this method is used to explain the laws whose problems are contained in the Qur'an and the Sunnahh.

The study of fiqh proposals around the bayani method includes three important aspects: First, analysis based on the meaning of lafaz or [بعتبار لفظ للمعنى]. Second, based on the use of the meaning [بعتبار استعمال اللفظ في المعنى]. Third, based on the light and vague meaning contained [ بعتبار كيفية دلالة اللفظ على المعنى بحسب ظهور المعنى المعنى وخفاءه]. Fourth, based on the terms of the appointment of lafaz according to the intention of the creator of the text [بعتبار كيفية دلالة اللفظ على المعنى].38

Second, the Ta'lili Method. This method is a method that functions to explore and determine the law of a case problem that is not found clearly or explicitly stated in the texts, and has not yet been determined by ijma ', but actually the law exists implicitly in the texts. Istinbat this type is intended to establish the law of an event with reference to the problems that already have the law first. Such issues as a mufti determine the law of an event that refers to events that already have a text. ${ }^{39}$

Jurists mentioned that most of the provisions of the law are illicit, because it is not appropriate for God to give rules without good aims and intentions. ${ }^{40} \mathrm{In}$ the al-Qur' an and the Hadis as explicitly mentioned illat, there are only hinted at, and some are not mentioned. The majority of texts that are not known are in the realm of pure worship (mahdah). The scholars have formulated ways to find

${ }^{37}$ Ma 'rūf Al-Dawālibī, Al-Madkhal Ila `Ilm Uşūl Al-Figh (Beirut: Dār al-Kitāb al-Jadīd, 1965).

${ }^{38}$ Ma`rūf Al-Dawālibī, Al-Madkhal Ila `Ilm Uşūl...

${ }_{39}$ Muhammad Salām Madkur, Manāhij Al-Ijtihād Fi Al-Islām (Kuwait: al-Maţba ah alAşriyyah, 1973).

${ }^{40}$ Muhammad Mustafa Sya 'labī, Ta'lil Al-Ahkām; 'Ard Wa Tahlil Li Tariqat Al-Ta'Lil Wa Tatawwuratiha Fi Usuf Al-Ijtihad Wa Al-Taqlid (Cairo: Dār al-Nahdāh al-`Arabiyyah, 1981). 
FITRAH Jurnal Kajian Ilmu-ilmu Keislaman

Vol. 05 No. 2 Desember 2019

illat ${ }^{41}$ from verses and hadith, ilat can be used practically and can be divided into three categories, namely ilat tasyri $i$, qiyasi, and istihsani. ${ }^{42}$

Third, the Islislahi Method. This method is used to examine and then formulate a syariah law. The method used is to establish a law for issues that do not yet have legal status, both in texts, ijma, it is not possible to use the qiyas or istihsan methods. So the principle in this third form of ijtihad is only maqashid of sharia law which aims to realize the benefit of humans, both in the form of bringing benefits or rejecting harm in preserving religion, life, reason, descent, and property. ${ }^{43}$

The reasoning process used in the istislahi method still refers to messages contained in the Qur'an and Hadith. For example, verses that order to be fair, must not harm themselves and others, that in every difficulty there must be a way.

Istislahi reasoning is done if the problem to be identified cannot be returned to any particular verse or hadith. Then there is no exact comparison from the time of the Holy Prophet, which can be used. As an example of the rules for making marriages, there is no comparison here from the sunnahh of the Holy Prophet, to regulate this problem. But managing this new problem is necessary because it involves the benefit of the people. Then this issue is accepted and can be applied. Another example is the case of the use of organs from a deceased person to be transplanted into a living person. In this case there is a conflict between giving help to perfect or save a living human being and damage to a corpse. If the benefit of rescue is greater than the mudlarat caused by its destruction, then transplantation is considered permissible. But for this example there are actually still many khilafiyah who followed it.

The method of istislahi is stated to have included various postulates of the maslahah of the mursalah, al-'urf, istishab which are the Muslim's guideline, all because the primary consideration of the ulama in accepting these propositions is the factor of prosperity.

41 Stages in the process of discovering illat: 1) takhrijj al-manāt, inventorying some properties that are suspected to be illic, 2) tanqīh al-manāt, selecting some properties that have been inventoried in the first stage, and 3) tahqīq al-manāt, proving the effectiveness of illat, can it be applied to furu' or not.

42 Sya 'labī, Ta'lil Al-Ahkām; 'Ard Wa Tahlil Li Tariqat Al-Ta'Lil Wa Tatawwuratiha Fi Usuf AlIjtihad Wa Al-Taqlid.

${ }^{43}$ Examples of maslahah mursalah are Abu Bakr's decision to fight those who are reluctant to pay zakat, and the obligation of qishash on the crowd who killed someone. Abdul Wahab Khalaf, 'Ilmu Ushul Al-Figh. 
The form of ijtihad bayani is accepted by all groups, including among Zahiriyah and Shi'a, but the form of ijtihad tahli\} li-qiyasi and istishlahi there are differences of opinion among scholars in using it. Hanafiyah, Malikiyah, and Hanabilah use these last two forms. Whereas Zahiriyah rejects the latter two forms absolutely, while Shafi'iyah restricts them to the second form which is only to the qiyas and rejects istihsan and rejects the third form or ijtihad that is outside the territory of the texts (nash). ${ }^{44}$

Basically the three istinbat methods mentioned above are efforts to find maqasid al-syariah (general purpose of sharia), namely to realize public benefit by providing benefits and avoiding interpretations for mankind which aims to preserve religion, soul, reason, descent, and property. The sharia maqasid can be achieved if the sharia orders are carried out as well as possible and vice versa the sharia prohibition is shunned.

\section{The Latest fatwas of Al-Lajnah al-Daimah Li al-Buhus al-Ilmiyah Wa al-Ifta ${ }^{45}$}

The methods and manhaj that are rolled out by the institution handle and respond to various questions about a problem at hand. Manhaj or the method of submission is a referee in obtaining legal certainty of an issue. Because the truth is not considered a fatwa when without using certain methodologies in the process of nesting or relying on things that are determined. The foundation of a fatwa is very dependent on some very crucial things in the process of istinbat alahkam, the foundation is the arguments syar'i either in the form of the Quran or the sunnahh of the Prophet, sometimes the reliance is on the rules of fiqh (the

${ }^{44}$ Madkur, Manāhij Al-Ijtihād Fi Al-Islām.

${ }^{45}$ The establishment of the institution of al-Lajnah al-Da imah Li al-Buhus Wa al-Ifta, or it can be called al-Lajnah ad-Da imah Li al-Fatwa, is on the Intrussi of King No. (1/137) dated 8/7/1391 H: The Council of Senior Ulema of Saudi Arabia was instructed to form a permanent Committee which was functioned from its members. The scope of work is to prepare scientific research needed by these institutions to be studied in scientific discussion forums, then issue edicts that are needed by the community in matters of faith, muamalat and personal law. The newly formed institution is called al-Lajnah al-Daimah Li al-Buhus Wa al-Ifta. The King's instructions contained an order to immediately establish an official state institution that functioned from the association of senior scholars in Saudi Arabia (هيئة كبار العلماء). The fatwa institution is in charge of two important rules in the country: First, issuing fatwas that are the needs of the community and issued verbally and textually. Second, prepare and carry out research or scientific work around contemporary issues or nawazil needed. With these two important tasks, it was instructed to establish a fatwa institution under Hai'ah Kibar al-Ulama known as al-Lajnah al-Da imah Li al-Buhus Wa al-Ifta. Abdurrahman bin Abdullah al-Jibrin, Minhaj Al-Fatwa Al-Lajnah Al-Daimah Li Al-Buhus Al-Ilmiyah Wa Al-Ifta Fi AlMamlakah Al-Arabiyah Al-Su'udiyah, Dirasah Usuliyah Tatbiqiyah Mujazah (Riyad: Majallat al-Jamiah al-Fiqhiyah Fi al-Mamlakah, 1430). 
FITRAH Jurnal Kajian Ilmu-ilmu Keislaman

Vol. 05 No. 2 Desember 2019

principles of fiqh (al-qawaid al-fighiyah) or oriented to the principle of benefit or to the core and purpose of the shari'a (maqasid al-shariah), and also sometimes to some opinions and thoughts of the salaf scholars from among friends, tabi'in and some others.

Before describing the method used by al-Lajnah al-Daimah Li al-Buhus alIlmiyah Wa al-Ifta in resting his fatwa, it is better to know the various opinions related to istinbat methodology in devotion, Ibn Salah explains the matter: a mufti should be brief in his fatwa pious, such as being sufficient with the permissible (yajuz) problem or may not (la yajuz), or correctly (haq) or correcting the truth (batil), it is not necessary to include the arguments which form the basis or ground in the piety, and in order to distinguish between fatwa and explanation (sharia). ${ }^{46}$ Al-Razi added that a mustafti does not need to question too much about the foundation or methodology used by a mufti, then it is sufficient only to know, then practice it, ${ }^{47}$ then al-Nawawi explains when a musftafti wants an explanation which is more about the law of an issue, then it is recommended to handle and study it deeply and personally for and sought by him. ${ }^{48}$

A mufti is also guided to explain the arguments that become the foundation and foundation in the legal istinbat, or the methodology in the law, when there is a person who asks a case and its arguments in detail, then it is allowed with a note to strengthen understanding and belief, and is not allowed to ask questions only modest or complementary and not the purpose. ${ }^{49}$

Therefore, it is necessary to have standard manhaj in the fatwa process and procedure used in determining the law of an issue, several stages which are always carried out by the al-Lajnah al-Daimah Li al-Buhus al-Ilmiyah Wa al-Ifta in the process of study up to by issuing fatwas including:

1. Always refer to and assert the arguments that are mututha: al-Qur'an, sunnah, Ijma 'and Qiyas. In the use and reliance on one of the propositions, among others, the hadith of the Holy Prophet, the traditions that are da'eef can be

${ }^{46}$ Ibnu Salah Usman bin Abdurrahman Abu Amr Taqiyuddin, Adab Al-Mufti Wa AlMustafti (Beirut: dar al-Rabbaniyah, 1994).

${ }^{47}$ Fakhruddin Muhamad bin Umar bin al-Husain Al-Razi, Al-Mahsul Fi Ilm Usul Al-Fikih (Beirut: Muassasah al-Risalah dan Markaz al-Nakhab al-`Ilmiyyah, 1430).

${ }^{48}$ Abi al-Qasim Abdul Karim bin Muhammad bin Abdul karim Al-RaFii, Al-Aziz Syarh AlWajiz: Al-Syarh Al-Kabir (Beirut: Dar al-Kutub al-Alamiyah, 1987).

49 Ibnu Sam'ani Al-Mustafa Mansur bin Muhammad bin Abdul al-Jabbar, Qawati' AlAdillah Fi Al-Usul (Beirut: Dar al-Kutub al-Alamiyah, 1994). 
used when these traditions are supported by other traditions that are similar in case (taddud al-turuq).

2. Making mukhtalaf arguments such as: istishab, qaul sahabi, al-urf, maqasid alshariah and fiqh rules which are widely used by the jurists are still used as consideration in deciding a problem.

3. Not inclined towards certain schools and schools of thought, as a basis for thinking on various issues and questions raised by Mustafti.

4. While the operational standard procedure in its fatwa, the institution is very concerned about various aspects that pay attention to ethics and eligibility, various aspects can be seen as follows:

a. Treats the same for all questions asked by accepting them immediately and processing them, and does not discriminate or neglect any of the questions for some reason.

b. Slowly and be careful in issuing fatwas, starting from the legal study to the issuance, and not being allowed to rush, too quickly in issuing fatwas because of the potential to reduce the accuracy of one issue.

c. Prioritize the principle of deliberation on every question that comes in.

d. Conduct a review of the fatwa that has been issued..$^{50}$

The legality in a fatwa is agreed upon and signed with each fatwa issued. Then the fatwa is immediately conveyed to the mustafti through various facilities determined by the institution based on the conditions and situation of the fatwa issued.

Some other things mentioned above are that regarding the deliberation in the fatwa process and procedure in the al-Lajnah al-Daimah Li al-Buhus al-Ilmiyah Wa al-Ifta institution is always through the deliberation process, the institution always invites or brings experts in certain fields when the topic is related to it, such as political or health issues, specialist doctors and political experts or experts in the field are also present. Ibn Salah in his kit said the recommendations and endeavored in the procedure of being obliged to communicate with experts who are in charge of a scientific discipline. ${ }^{51}$

Its function and role in the Islamic legal issues encountered is as stated in the king's instruction (1/137) dated 8/7/1391 $\mathrm{H}$ mentioned earlier, the intrusion basically became the basis for establishing the fatwa of the Saudi Arabian state, since then institutions that are involved in fatwa matters are formally formed, with authority granted, among others: First, issuing fatwas that are the needs of

\footnotetext{
${ }^{50}$ Abdurrahman bin Abdullah al-Jibrin, Minhaj Al-Fatwa Al-Lajnah Al-Daimah Li Al-Buhus Al-Ilmiyah Wa Al-Ifta Fi Al-Mamlakah Al-Arabiyah Al-Su'udiyah, Dirasah Usuliyah Tatbiqiyah Mujazah.

${ }^{51}$ Usman bin Abdurrahman Abu Amr Taqiyuddin, Adab Al-Mufti Wa Al-Mustafti.
} 
FITRAH Jurnal Kajian Ilmu-ilmu Keislaman

Vol. 05 No. 2 Desember 2019

the community and issued verbally and textually. Second, prepare and carry out scientific research around current issues or nawazil needed by the state or society. ${ }^{52}$

Scope of the Fatwa At the beginning of the establishment of the al-Lajnah alDaimah Li al-Buhus al-Ilmiyah Wa al-Ifta to be more productive in highlighting themes around theology, fiqh of worship and those that are related to personal fiqh mu'amalat alone. However, Ahmad Abdurrazak al-Duwaisi in 1434 coincided with 2003 as the compiler and compiler of the fatwas issued by the alLajnah Ad-Daimah Li al-Buhus Wa al-Ifta institution mentioning the fatwas covering several religious themes surrounding: 1) Theology (aqaid), 2) al-Qur'an along with the sciences about it (al-qur'an wa ulumuh), 3) fiqh laws that are personal (al-figh al-syakhsiyat), 4) then equipped with discussions that include multi-disciplinary, both about ethics in the daily lives of a Muslim to nonMuslims (kitab al-jami), including to date various edicts have been published in study 5) Jurisprudence of al-siyasah (politics) and also entering territory 6) economics both conventional and sharia (iqtisad)..$^{53}$

The fatwas issued in general by the institute have been very productive in the fatwa process on the issues raised by Mustafti, until now it has issued various fatwas around nawazil issues faced by people in various regions, both in their own country and various research circles, students of religious knowledge, or religious leaders who also use it as a proof in answering the problems of today's society. In quantity, the agency had issued 28,800 (twenty-eight thousand eight hundred) fatwa until 2013 or averaged 600 fatwas annually. ${ }^{54}$ Here are some of them that are related to the theme of Islamic family law;

First, Fatwa for being able to owe money for marriage or to give dowry in marriage. The fatwa was issued answering a question of a young man who was classified as economically disadvantaged, but his desire to get married was classified as compulsory for him, so the young man complained about the problem to the institution which received an answer with fatwa no 10322, with the title fatwa [الدين من أجل الصداق] , the fatwa is;

${ }^{52}$ Ahmad bin Abdurrazak al-Duwaisi, Fatawa Al-Lajnah Al-Daimah Li Al-Buhus Al-Ilmiyah Wa Al-Ifta (Riyad: Dar al-Muayyid, 1409).

53 Ahmad bin Abdurrazak al-Duwaisi, Fatawa Al-Lajnah.....

${ }^{54}$ Abdurrahman bin Abdullah al-Jibrin, Minhaj Al-Fatwa Al-Lajnah Al-Daimah Li Al-Buhus Al-Ilmiyah Wa Al-Ifta Fi Al-Mamlakah Al-Arabiyah Al-Su'udiyah, Dirasah Usuliyah Tatbiqiyah Mujazah. 


$$
\text { لا لا حرج على مريد الزواج إذا كان لا يجد المال أن يستدين مبلغا, أو يقترض قرضا بالطريق الشرعية إذا كان ينوي }
$$

It's okay for someone who wants to have a marriage, when they don't have enough assets to owe sufficiently, or apply for a loan to a financial institution in a sharia way, when he or she intends to fulfill that intention.

The fatwa provides leeway and ease in the process of carrying out Islamic law, namely marriage, which most people have many daily needs, so single, or many old girls are found due to various reasons, economic factors, employment, family conditions or others Therefore, the emergence of the fatwa alleviates cases that are considered sacred in its implementation. The fatwa can be summarized as follows;

1. May the law owed for the purposes of marriage, either preparing the bride itself or other financing.

2. Loans can be obtained from other financial financing institution.

3. Prohibition of applying for loans to institutions or individuals that are not based on sharia values, or conventional, in the sense that the loan develops and there is usury there.

4. Obtaining debt to finance the marriage is within adequate limits, not for rahrah or excess in the implementation of the marriage.

Second, Fatwa prohibits accepting traditions that are taking place in certain societies, those traditions are the culture of the community where when there is a young man and woman going to get married, then the community that has already entered into a marriage is charged and even obliged to collect these selfhelp funds, which it was mentioned by the questioner that the fatwa was in the amount of five hundred riyals of Saudi Arabia, that number was considered burdensome for the local community. This is the background of a young man to convey the problem to the institution, and immediately respond to the matter by issuing a fatwa with number 14571 . The fatwa is;

$$
\text { فإذا كان الأمر كما ذكر فلا يجوز, أما من أحب أن يساعد أخاه, أو قريبه من دون إلزام ولامعاوضة ممن يساعده }
$$

${ }^{55}$ Ahmad bin Abdurrazak al-Duwaisi, Fatawa Al-Lajnah Al-Daimah Li Al-Buhus Al-Ilmiyah Wa Al-Ifta.

${ }^{56}$ Ahmad bin Abdurrazak al-Duwaisi, Fatawa Al-Lajnah Al..... j.19, h.50. 
FITRAH Jurnal Kajian Ilmu-ilmu Keislaman

Vol. 05 No. 2 Desember 2019

If the reality as stated in the question, then it is prohibited to accept, even the culture is considered difficult for various things. However, if the contribution is intended to alleviate the difficulties and difficulties of the bride and groom, then it is considered permissible.

The fatwa is related to the transmission of a society, namely in the study of fiqh ushul included in al-urf. ${ }^{57}$ The study emphasizes that culture or tradition can be accepted and absorbed and have a position in Islamic law, in other words that al-'urf or culture of a group of people in Islamic law can be classified into types. For al-'urf sahih he has a legal position that deserves to be preserved because it is a habit that is positive and does not conflict with syariah law 'to be done and maintained. Therefore, the scholars hold that customary law is permanent (العادة المحكمة).

The position of al-'fac fasid in Islamic law is not worth preserving because it is a habit that is negative and and contrary to syariah law ', so it is not necessary to do and maintain. Basically al-'urf is an unwritten law. It grows and develops according to the development of a society.

The fatwa above can be carried out or taken advantage of in various elements of society, or various tribes which among one another have their own local wisdome. This can not be avoided, but can be sorted by using the fatwa that things or cultures that are far from the teachings of Islam cannot be justified. The fatwa can be interpreted as follows;

1. Culture burdensome others or seems to force it cannot be justified. Especially with regard to economic issues, because each person with another has different economic conditions. Therefore, the sanctions imposed on the community are not justified in Islamic law.

2. The contribution contribution culture which has become a culture in a wide variety of societies, is generally justified, when it is based on the principle of helping one another [التعاون].

3. The prohibition was due to an element of coercion. And the acquisition of the fatwa is the element of please helping fellow human beings.

Third, Fatwa is prohibited from giving dowry only partly and for others at a later time. The fatwa was issued on a question from one of the people who asked

${ }^{57} \mathrm{Al}$-Urf is; What has become a habit of humans and they agree either in actions that are widespread among them or the words that when spoken they know the meaning specifically that there will be no other meaning that comes to mind when they hear the word. Wahbah Mustafa alZuhaili, Al-Wajiz Fi Usul Al-Figh (Damaskus: Dar al-Fikr, 1999). 
the ability to give dowry agreed by the family consensus was 2000 (two thousand) riyals of Saudi Arabia. So what is asked is when the dowry is given 1000 (one thousand) riyals at the time of the marriage contract, and the remainder of the dowry to be granted will be repaid at a later time. The fatwa was issued with number 3823 for the response from the questioner. The fatwa is;

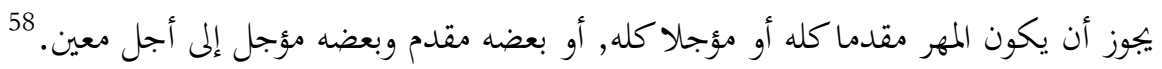

It is permissible to make dowry in marriage by giving it all at the beginning of the marriage, that is when the marriage contract takes place, or the dowry of marriage is given entirely on hold, or given partly at the time of the marriage contract, and some others are given at the specified and agreed period.

The fatwa concerns the rights that must be fulfilled in the implementation of the marriage contract, which is the obligation agreed upon by the majority, which is to give a wedding dowry. ${ }^{59}$ The essence of the fatwa is;

1. It is not permissible to give dowry marriage in installments for which there is no clear time in it.

2. May give a wedding dowry at the agreed time. For example, the dowry is to perform the pilgrimage together with a husband and wife. Then the dowry cannot be fulfilled immediately because the time can only be carried out on Zulhijjah alone.

3. Prohibition of giving dowry marriage with unclear time, let alone its shape, for example, the dowry as wrapped in this box.

Fourth, Fatwa uses drugs so that the uterus cannot get pregnant again. This was asked by one woman who had 13 children (thirteen) children, some of whom were still toddlers, the woman felt tired in caring for her many children, then the agreement of husband and wife was to use daycare services children, and there is a woman who helps with the care of her children every day. These conditions make the woman have thoughts of taking medicine so that she is no longer pregnant. Regarding this issue, the institution issued a fatwa number 1563, as follows;

${ }^{58}$ Ahmad bin Abdurrazak al-Duwaisi, Fatawa Al-Lajnah Al-Daimah Li Al-Buhus Al-Ilmiyah Wa Al-Ifta.

${ }^{59}$ Ibnu Irawan, "Mahar Hafalan Al- Qur'an Perspektif Hukum Islam," PALITA: Journal of Social-Religion Research 4 (2019): 121-36, https://doi.org/https://doi.org/10.24256/pal.v4i2.804. 


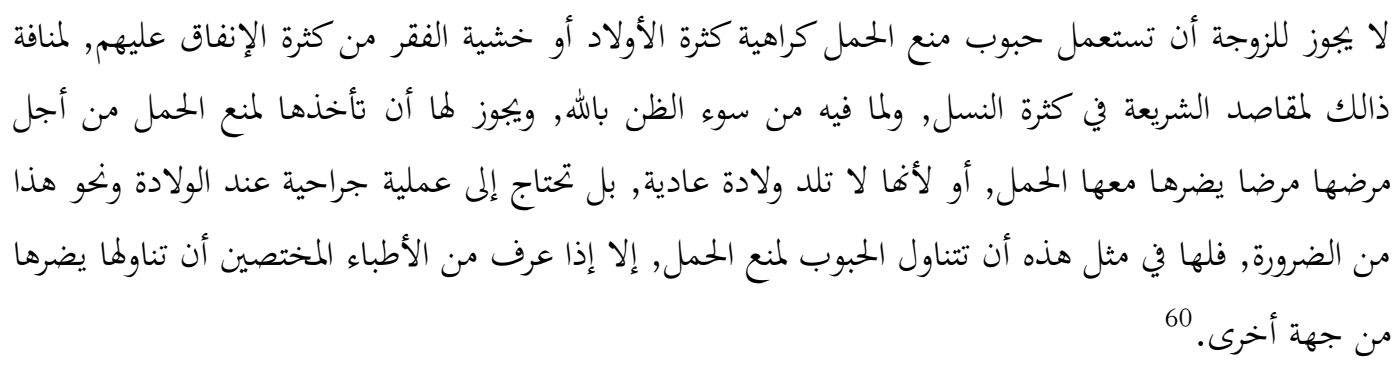

It is not permissible for a wife to use drugs that cause her uterus to not be able to get pregnant, this is done for fear of too many children or fear of not being able to pay for the livelihoods of her children, it is prohibited because it is contrary to the Maqasid alShariah who also take care of offspring, or the number of offspring, it is also considered a bad form of prejudice against Allah. Pregnancy barrier drugs may be used with the aim of not getting pregnant with a few exceptions; for reasons of self the woman has an illness that can affect the condition of her uterus, or the fetus in it when pregnant, or because in the previous labor process the woman gave birth by the process of cranial, and various things that could potentially cause other dangers. Because of such conditions in the second part of taking drugs so that they can not get pregnant for reasons based on conditions endangering themselves or others.

The fatwa above is related to the issue of one's household or family structure, which mentioned family has many family members, namely several children. Concerns, as well as other aspects, affect the mind to find solutions to the problems it faces. The fatwa contains several laws that can be interpreted, including;

1. Taking drugs that cause her uterus to be blocked from pregnancy because there are too many children, fearing that she cannot support her children, is prohibited.

2. Legal use of these drugs may be legal when for reasons of six or the potential when the uterus fills with a fetus will potentially cause harm to the fetus.

3. Obtaining these drugs is also for a woman who gave birth by the process of Ceasar because of the process of healing from the influence of sewing operations in the abdomen.

4. The fear of having many children is not under maqasid al-syariyah.

5. An attitude of worry over not being able to support the children who are mandated is one form of prejudice to Allah Almighty.

\footnotetext{
${ }^{60}$ Ahmad bin Abdurrazak al-Duwaisi, Fatawa Al-Lajnah Al-Daimah Li Al-Buhus Al-Ilmiyah
} Wa Al-Ifta. 
Fifth, Fatwa related to caring for toddlers whose mothers are at work, while the condition of his father when he heard the call to prayer and wanted to perform the prayer of the toddler will be alone in the house, because his wife has not returned when the call to prayer echoes (azan ashar), it is an issue that is asking to the party institutions through electronic mail that received a response in the form of fatwa number 19335. As the following fatwa;

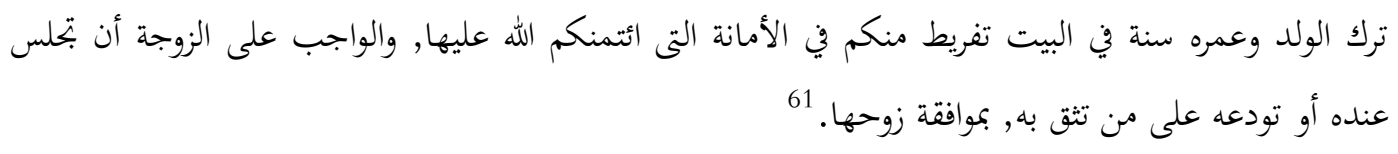

Leaving a one-year-old child in the house alone is a form of the carelessness of the mandate that Allah Almighty left. A wife should accompany her when a husband wants to carry out his five-time obligation in the mosque. When the wife is unable to leave, it is permissible to entrust the child to a person or place that is trusted to temporarily care for the child, which of course, is with the wife's consent.

Fatwa above is related to the condition of a modern family, where a wife has a busy work outside the home, it is permissible when all obligations that exist at home have been completed. The fatwa as mentioned above is a directive as well as aimed at the Muslim community today, with the issuance of the fatwa, the following conclusions can be drawn ;

1. Prohibition of leaving a toddler alone in the house, or other places

2. Prohibition of leaving the family in an insecure condition, even though the going is for reasons that are obligations

3. The law of origin of a woman is to be at home, and not allowed to leave the house without the permission of her husband

4. It is possible to leave the care of a child to someone else who can be trusted

5. Prompts to always communicate between husband and wife, so there are no misunderstandings between the two. Because basic woman, when asked for her opinion, is a form of appreciation for a man to a woman who is his wife.

\section{CONCLUSION}

Conclusions from the discussion of the article above are; First, the methodology used: 1) Always refer to and assert the arguments that are muttafaq: al-Qur'an, sunnah, Ijma 'and Qiyas. 2) Making the arguments that are mukhtalaf such as: istishab, qaul sahabi, al-urf, maqasid al-sharia, and fiqh rules

${ }^{61}$ Ahmad bin Abdurrazak al-Duwaisi, Fatawa Al-Lajnah..... 
FITRAH Jurnal Kajian Ilmu-ilmu Keislaman

Vol. 05 No. 2 Desember 2019

which are widely used by the jurists are still use as consideration in deciding a problem. 3) Not inclined towards certain schools and schools of thought, as a basis for thinking on various issues and questions raised by Mustafti.

Second, the progression of the fatwas issued, among others; 1) Fatwa for obtaining indebtedness for marriage number 10322. 2) Fatwa prohibiting accepting traditions that are taking place in certain societies and contrary to religion is an issue with number 14571. 3) Fatwa prohibiting giving dowry only partly and others at a later time without the certainty of time, issued with number 3823. 4) Fatwa on the use of drugs so that the uterus cannot get pregnant again. 5) Fatwa related to caring for children under five whose mothers are at work, issued fatwa number 19335. 


\section{REFERENCES}

Abdul Wahab Khalaf. 'Ilmu Ushul Al-Fiqh. Cairo: Maktabah Da'wah Islamiyah, 1947.

Abdurrahman bin Abdullah al-Jibrin. Minhaj Al-Fatwa Al-Lajnah Al-Daimah Li AlBuhus Al-Ilmiyah Wa Al-Ifta Fi Al-Mamlakah Al-Arabiyah Al-Su'udiyah, Dirasah Usuliyah Tatbiqiyah Mujazah. Riyad: Majallat al-Jamiah al-Fiqhiyah Fi alMamlakah, 1430.

Abi Amr Jamaluddin Usman bin Umar bin Abi bakr, Ibnu al-Hajib. Syarh Al-Adhi 'Ala Mukhtashar Al-Muntaha. Beirut: Dar al-Kutub al-Alamiyah, 2000.

Abu al-Husain Ahmad bin Faris Zakaria. Mu'jam Maqayis Al-Lughah. Beirut: Dar al-Fikr al-Arabi, n.d.

Ahmad bin Abdurrazak al-Duwaisi. Fatawa Al-Lajnah Al-Daimah Li Al-Buhus AlIlmiyah Wa Al-Ifta. Riyad: Dar al-Muayyid, 1409.

Ahmad bin al-Hasan bin Ali bin Musa al-Khusraujidi al-Khurasan, Abu Bakr alBaihaki. Al-Sunan Al-Kubra. Beirut: Dar al-Kutub al-Alamiyah, 1424.

Al-Abyari, Ibrahim. Al-Ta'rifat Li Al-Jurjani. Beirut: Dar al-Kutub al-Arabi, 1405.

- - . Al-Ta'rifat Li Al-Jurjani. Beirut: Dar al-Kutub al-Alamiyah, 1405.

Al-Amidi, Ali Muhammad. Al-Ihkam Fi Ushuli Al-Ahkam. Riyad: Dar al-Shami'i Li al-Nasyri Wa al-Tauzi, 2003.

Al-Bahuti. Syarh Muntaha Al-Iradiyat. Beirut: Dar al-Fikr al-Arabi, n.d.

Al-Dawālibī, Ma 'rūf. Al-Madkhal Ila 'Ilm Uşūl Al-Fiqh. Beirut: Dār al-Kitāb alJadīd, 1965.

al-Fairuz Abadi. Al-Qamus Al-Muhit. Cairo: al-Hai'ah al-Ilmiyah al-Misriyah, n.d.

Al-Khail, Sulaiman bin Abdullah bin Hamud Aba. Masadir Al-Din Al-Islami Wa Abraz Mahasinuh Wa Mazayah. Riyad: Muassasah al-Risalah, 1431.

Al-Khatib, Muhammad Ajjaj. Ushul Al-Hadis Ulumuhu Wa Mustalahahu. Beirut: Dar al-Fikr al-Arabi, 1989.

Al-Kindi, Abdurrazak Abdullah Salih bin Ghalib. Al-Taisir Fi Al-Fatwa Asbabuhu Wa Dawabituhu. Beirut: Muassasah al-Risalah Nasyirun, 2008.

Al-Mustafa Mansur bin Muhammad bin Abdul al-Jabbar, Ibnu Sam'ani. Qawati' 
FITRAH Jurnal Kajian Ilmu-ilmu Keislaman

Vol. 05 No. 2 Desember 2019

Al-Adillah Fi Al-Usul. Beirut: Dar al-Kutub al-Alamiyah, 1994.

Al-Qardawi, Yusuf. Al-Fatwa Baina Al-Indhibat Wa Al-Tassaub. Cairo: Dar alSahwah Li al-Nasyr Wa al-Tauzi, 1988.

Al-RaFii, Abi al-Qasim Abdul Karim bin Muhammad bin Abdul karim. Al-Aziz Syarh Al-Wajiz : Al-Syarh Al-Kabir. Beirut: Dar al-Kutub al-Alamiyah, 1987.

Al-Razi, Fakhruddin Muhamad bin Umar bin al-Husain. Al-Mahsul Fi Ilm Usul Al-Fikih. Beirut: Muassasah al-Risalah dan Markaz al-Nakhab al-'Ilmiyyah, 1430 .

Al-Sam'ani, Abu al-Muzafar Mansur bin Muhammad bin Abdul Jabbar Ibnu Ahmad al-Maruzi. Qawati Al-Adillah Fi Al-Usul. Beirut: Dar al-Kutub alAlamiyah, 1998.

Al-Sāyis, Muhammad 'Ali. Nasy'ah Al-Figh Al-Ijtihād Wa Ațwāuh. Jakarta: Raja Grafindo Persada, 1995.

Al-Suyūţī, Abu Bakr Jalāluddīn. Al-Rad 'Ala Man Akhlada Ila Al-Ardh Wa Jahl Anna Al-Ijtihad Fi Kulli 'Ashr Fardh. Cairo: Maktabah al-Saqafah al-Diniyyah, 2000.

Al-Syaukānī, uhammad `Ali ibn Muhammad. Irsyād Al-Fukhūl Ilā Tahqīq Al-Haqq Min 'Ilm Al-Uşūl,. Beirut: Dār al-Kutub al-'Ilmiyyah, 1994.

Al-Syinqiti, Muhammad al-Muqlub. Syarh Al-Waraqat Fi Usul Al-Fiq. Beirut: Wazarat al-Auqaf Wa al-Tauzi', 2001.

Al-Zarqa', Mustafa. Al-Figh Al-Islami Wa Madarisuhu. Beirut: Dar al-Qalam Li alTab'ah Wa al-Nasyr Wa al-Tauzi', 1996.

Djamil, Fathurrahman. Metode Ijtihad Majlis Tarjih Muhammadiyah. Jakarta: Logos Wacana Ilmu, 1995.

Haekal, Muhammad Husain. Hayat Muhammad. Cairo: Dar al-Ma'rifah, 1995.

Hasan bin Ammar bin Ali al-Syarniblali, Muraqi al-Falah Bi Imad al-Fattah. Muraqi Al-Falah. Edited by Dar al-Kutub Al-Alamiyyah. Beirut, 2004.

Ibnu Irawan. "Mahar Hafalan Al- Qur'an Perspektif Hukum Islam." PALITA: Journal of Social-Religion Research 4 (2019): 121-36. https://doi.org/https://doi.org/10.24256/pal.v4i2.804.

John L. Esposito. "The Oxford Encyclopedia of The Modern Islamic World." "Fatwa" II (1990): 13. 
Madkur, Muhammad Salām. Manāhij Al-Ijtihād Fi Al-Islām. Kuwait: al-Maţba ah al-Aşriyyah, 1973.

Mahjuddin. Masail Al-Fiqh. Jakarta: Penerbit Kalam Mulia, 2012.

Muhammad al-Khudurī Bek. Ushul Al-Fiqhi. Beirut: Dar al-Fikr al-Arabi, 1988.

Muhammad bin Mukrim bin Ali, Abu al-Fadl, Jamaluddin Ibnu Manzur. Lisan Al-Arab. Beirut: Dar Shadir, 1414.

Nasrun Rusli. Ijtihad Al-Syaukani. Jakarta: Logos Wacana Ilmu, 1999.

Sa'di Abu Habib. Al-Qamus Al-Fiqhi. Damaskus: Dar al-Fikr al-Arabi, 1988.

Subki, Tajuddin Abdul al-Wahab Ibnu. Hasyiah Al-Allamah Al-Banani Ala Jam'i AlJawami' Bi Syarh Al-Muhalla. Beirut: Dar al-Halabi, 1997.

Sya 'labī, Muhammad Mustafa. Ta'lil Al-Ahkām; 'Ard Wa Tahlil Li Tariqat Al-Ta'Lil Wa Tatawwuratiha Fi Usuf Al-Ijtihad Wa Al-Taqlid. Cairo: Dār al-Nahdāh al'Arabiyyah, 1981.

Syihabuddin al-Qarafi. Al-Zakhirah. Beirut: Dar al-Gharb al-Islami, 1944.

Ubadah, Anis. Tarikh Al-Figh Al-Islami 'Ahd Al-Nubuwwah Wa Al-Sahabah Wa AlTabi'In. Cairo: Dar al-Fikr al-Arabi, 1980.

Usman bin Abdurrahman Abu Amr Taqiyuddin, Ibnu Salah. Adab Al-Mufti Wa Al-Mustafti. Beirut: dar al-Rabbaniyah, 1994.

Wahbah Mustafa al-Zuhaili. Al-Wajiz Fi Usul Al-Figh. Damaskus: Dar al-Fikr, 1999.

Zahrah, Muhammad Abu. Usul Al-Figh. Cairo: Dar al-Fikr al-Arabi, 1997. 
FITRAH Jurnal Kajian Ilmu-ilmu Keislaman

Vol. 05 No. 2 Desember 2019

\title{
LEARNING MODEL OF OLD TEACHERS (SAYYID IDRUS BIN SALIM ALJUFRI) IN SPREADING ISLAM IN CENTRAL SULAWESI
}

\author{
Prof. M.ASY'ARI \& BAHDAR \\ IAIN Palu, Sulawesi Tengah \\ Email: asyari1204@gmail.com ; \& habibbahdar03@mail.com \\ DOI: $h$ ttp://dx.doi.org/10.24952/fitrah.v5i2.2001
}

